\title{
DISJUNÇÃO, DUALISMO E DIALÉTICA: SOBRE A CRÍTICA LITERÁRIA BRASILEIRA E SENHORA, DE JOSÉ DE ALENCAR
}

\section{DISJUNCTION, DUALISM AND \\ DIALECTICS: ON THE BRAZILIAN LITERARY CRITICISM AND SENHORA, BY JOSÉ DE ALENCAR}

\section{Camila Hespanhol Peruchi* UNICAMP}

Resumo: Este artigo se divide em duas partes. A primeira delas recupera criticamente o pensamento teórico central de Antonio Candido e Roberto Schwarz no que concerne à relação entre a experiência sócio-histórica brasileira e a especificidade da formalização estética da nossa literatura. Ao historicizar ambos os posicionamentos, torna-se possível identificar, neste profícuo diálogo entre duas gerações críticas, continuação, diferenças e rupturas. Feito isso, a segunda e principal parte deste trabalho analisa o romance Senhora, de José de Alencar. Trata-se de uma revisão de caso. Recorrendo à crítica de Schwarz, apresentamos uma hipótese de leitura que, sem abrir mão do pressuposto argumentativo do crítico, diverge da sua conclusão. A nossa hipótese é de que, diferentemente do que aponta Schwarz, há um imbricamento entre a descrição da realidade brasileira e a formalização do enredo do romance. A conclusão é de que já há em Senhora o hibridismo brasileiro de pertencimento inacabado ao capitalismo, o que permite atribuir a este romance uma lógica de base que será observada pela crítica apenas na ficção brasileira posterior.

Palavras-chave: Crítica literária brasileira. Antonio Candido. Roberto Schwarz. Senhora.

\begin{abstract}
This paper is divided into two parts. The first one characterizes the theoretical thinking of Antonio Candido and Roberto Schwarz regarding the relationship between Brazilian social and historical experience and the specificity of the aesthetic formalization of Brazilian literature. By historicizing both positions in this fruitful dialogue between two critical generations it is possible to identify continuation, differences, and ruptures. The second and main part of this work analyzes the novel Senhora, by José de Alencar. This is a case review. Turning to Schwarz's critique, we present a hypothesis of reading that uses the argumentative assumption of the critic, but diverges from his conclusion. Our hypothesis is that, unlike what the critic points out, there is an imbrication between the description of the Brazilian reality and the formalization of the novel's plot. The conclusion is that there is an unfinished belongingness to Brazilian capitalism in Alencar's Senhora
\end{abstract}

\author{
${ }^{*}$ Mestre em Letras \\ pela Universidade \\ Estadual de Maringá \\ (UEM). Doutoranda \\ em Teoria e \\ História Literária \\ na Universidade \\ Estadual de Campinas \\ (UNICAMP). E-mail: \\ camila.peruchi@ \\ gmail.com
}


which allows gives the novel a logic that will be observed by the literary criticism only in the later Brazilian fiction.

Keywords: Brazilian Literary Criticism. Antonio Candido. Roberto Schwarz. Senhora.

Partindo da noção basilar de que a literatura se relaciona intrinsecamente com as condições concretas que a origina, Schwarz (2000) analisa como a experiência social e o sistema de ideias presentes no Brasil do século XIX contribuíram para a expressão e formalização estética da literatura brasileira. No centro de seu argumento repousa aquilo que é compreendido como a situação peculiar do Brasil e sua incongruência fundamental: a conjunção do capitalismo e da escravidão. Se a Europa vivenciava, ainda no século XVIII, uma revolução burguesa e consolidava o elemento essencial de qualquer revolução - a mudança na forma de trabalho (a instituição do trabalho assalariado) e o fundamento de uma nova sociabilidade (a formação ideológica do sujeito burguês) -, o Brasil assistiria a abolição da escravidão só em 1888. A contradição entre o eflúvio dos ideais liberais europeus e a realidade escravocrata e paternalista brasileira, marcada pelas relações de favores, se constituiria, assim, para Schwarz (2000), em um dos fatores determinantes de nossa experiência social. O argumento é tributário do trabalho de, ao menos, duas gerações de intelectuais que, ao tomarem a dinâmica centro-periferia como chave interpretativa do Brasil, investigaram, cada um a seu modo, os seus desdobramentos morais, políticos e culturais. Oliveira Viana, Gilberto Freyre, Sérgio Buarque de Hollanda, Caio Prado Júnior e Florestan Fernandes, apenas para citar alguns, são exemplos dessa perspectiva.

Não se pode negar, no entanto, que o trabalho dessa primeira geração foi marcado também por uma perspectiva ideológica. Ao buscar definir uma identidade para o Brasil, ela não apenas descreveu nosso país, mas propôs um projeto político futuro que, em certa medida, precedia a análise. Ao desfazer a ilusão de que nosso desenvolvimento histórico e social correspondia ao europeu, essa geração, animada por certo ideal de país, acabava por criar outro engodo: o de que o descompasso poderia ser superado. Guardadas as devidas proporções, pode-se dizer que o interesse dos autores recaía, assim, nos obstáculos ao desenvolvimento do capitalismo brasileiro no intuito, nem sempre explícito, de superar o atraso. Além da idealização do universalismo e do capitalismo contida na premissa, a definição de nosso país aparecia apenas por meio da comparação com a Europa e pautava-se por uma esquematização muitas vezes dual, instaurando uma distância que nos rebaixava (ARANTES, 1992). Desse rebaixamento, a literatura não esteve isenta. Candido (2000), em sua importante obra Formação da Literatura Brasileira, interpreta a nossa tradição literária a partir da conformação de dois polos: a lógica universal e o dado local. Partindo dos conceitos de sistema literário e acumulação literária, Candido captou, no filtro cultural 
das formas literárias, a experiência brasileira pautada nessa dialética. ${ }^{1} \mathrm{~A}$ posição, no entanto, não deixa de estar subordinada ao pensamento crítico hierárquico, uma vez que a sua análise da literatura brasileira lança mão de um valor estético consolidado, equivalente ao cânone ocidental. "Arbusto de segunda ordem no jardim das Musas” (CANDIDO, 2000, p. 9), "pobre e fraca” se comparada às grandes, caberia a nossa literatura ser também um “documento eloquente da rarefação da densidade espiritual”, absolvida, no entanto, pela vontade de se constituir, pelo empenho nacionalista:

Há literaturas de que um homem não precisa sair para receber cultura e enriquecer a sensibilidade; outras que só podem ocupar uma parte da sua vida de leitor, sob pena de lhe restringir irremediavelmente o horizonte. Assim, podemos imaginar um francês, um italiano, um inglês, um alemão, mesmo um russo e um espanhol, que só conheçam os autores da sua terra e, não obstante, encontrem neles o suficiente para elaborar a visão das coisas, experimentando as mais altas emoções literárias. Se isto já é impensável no caso de um português, o que se dirá de um brasileiro? (CANDIDO, 2000, p. 9)

Reconhecemos, evidentemente, a importância do trabalho de Candido (2000) ao realizar uma genealogia de nossa literatura atrelada à experiência social e à construção de uma identidade nacional, apresentando, para isso, uma concepção materialista de tradição elaborada pela primeira vez nesses termos. O fato de, sessenta anos depois, ainda suscitar questões é prova de sua validade e dimensão consequentes. ${ }^{2}$ De sua importância advém a necessidade de, distanciados historicamente de seu trabalho, historicizá-lo para não perder de vista uma justa compreensão do espírito democrático e internacionalista de seu autor, empenhado, enquanto homem de seu tempo, em desprovincianizar. ${ }^{3}$ A indicação aqui do caráter dual fundado na comparação e no critério canônico de valor ${ }^{4}$ tem antes a intenção de evidenciar a natureza complexa que caracterizou qualquer empenho em interpretar a formação do Brasil, “periferia do sistema capitalista”, para retomar os termos que, mais tarde, seriam empregados por Schwarz (1990). Assim, nem Carlos Drummond de Andrade escapou às influências do dualismo tomado como desvantagem. Em carta a Mário de Andrade, Drummond (2015, p. 13) confessa: "Pessoalmente, acho lastimável essa história de nascer entre paisagens incultas e sob céus pouco civilizados [...]. Acho o Brasil infecto”. E acrescenta, indignado: "Detesto o Brasil como a um ambiente nocivo à expansão do meu espírito. Sou hereditariamente europeu, ou antes: francês”. Mário responderia no mesmo tom de indignação, mas em outra direção. Negando a existência de uma oposição entre nacionalismo e universalismo e reconhecendo o desejo ingênuo dos brasileiros de obrigar o Brasil a incorporar-se ao movimento universal das ideias, Mário evoca ironicamente os versos da Pauliceia: "As esmeraldas das araras, / Os rubis dos colibris / Os lirismos dos sabiás e das jandaias, / Os abacaxis, as mangas,
${ }^{1}$ Nesse sentido, pode-ser dizer que Formação da Literatura Brasileira, publicada em 1959, já aponta para uma direção crítica que se desenvolverá plenamente em ensaios como Dialética da Malandragem, de 1970.

${ }^{2}$ Schwarz (1999), em ensaio sobre o livro de Candido, destaca algumas características fundamentais desta obra que, segundo o crítico, já nasceu um clássico: o não nacionalismo (já que entrega a Portugal alguns de nossos autores), o vínculo não subserviente a várias obras que procuraram pensar a formação do Brasil em outros níveis e a explanação praticamente inédita da literatura anterior ao século XX.

${ }^{3}$ Como evidencia Costa Lima (1992), na década de 1950 , a história literária era a meta almejada pelo crítico, pois a literatura era considerada parcela integrante e realizadora do espírito nacional. Nesse sentido, constituir solidamente essa literatura também era um desejo de Candido, explícito em Formação. A obra de Candido, portanto, reflete um sentimento que, ao menos até os anos 60, era frequente na intelligentsia dos povos jovens. Schwarz (1999), 
os cajus / Almejam localizar-se triunfantemente, / Na fremente celebração do Universal!...” (2015, p. 14).

Ao recuperar a matriz histórica do conflito entre localistas e universalistas e identificarmos essa espécie - para continuarmos nos termos de Mário - de "recalque" de nossa intelligentsia nacional, somos convidados a tomar consciência do caráter paradoxal dos critérios valorativos que cabiam a uma colônia e, sobretudo, dos caminhos controversos que caracterizaram, em países como o nosso, a inteligência crítica, sempre às voltas com seus pares antitéticos: Brasil/Europa, arcaico/moderno, localismo/cosmopolitismo, tendências literárias universalistas/particularistas etc. Não é preciso recorrer a mais exemplos, portanto, para notarmos como, em nosso país, "o dualismo é concepção de largo espectro" (ARANTES, 1992, p. 23), a ser, por isso mesmo, constantemente retomado e revisto. Não por acaso, portanto, em meados da década de 1950, Fernando Novais, Emília Viotti da Costa, Luiz Felipe de Alencastro, Maria Sylvia de Carvalho Franco, Fernando Henrique Cardoso, Francisco de Oliveira e Paulo Arantes expandiram as ideias já desenvolvidas pela primeira geração de intelectuais mencionada e repararam antigas limitações dualistas. Tanto Candido, quanto Schwarz tiveram o mérito de pressentir as implicações literárias da revisão então em curso dos grandes modelos interpretativos das origens do Brasil contemporâneo. No entanto, pode-se dizer que Formação da literatura brasileira se desenvolve num tempo em que a ideia de formação parecia viável, ${ }^{5}$ diferentemente da obra de Schwarz que, publicada no fim da década de 70, assinala a desqualificação da ideia de formação pelo próprio rumo da história. ${ }^{6}$ Como aponta o próprio Schwarz (1990), a integração feliz de nosso país ao movimento geral da modernização capitalista já não é mais esperada e talvez - com certo cinismo indiferente ou desesperança melancólica - tenhamos abandonado por completo qualquer ilusão restante a respeito dela.

A novidade no passo adiante dado por Schwarz reside, portanto, menos na apropriação da dinâmica particular-universal (periferia-centro) para pensar a peculiaridade da nossa literatura (o que já tinha feito, em grande medida, Antonio Candido) e mais no fato de, ao fazê-lo, ter se centrado em um momento de integração e síntese desses polos opostos, o que culminaria na conjunção disparatada de ambos: "Contrariamente ao que as aparências de atraso fazem supor, a causa última da absurda formação social brasileira está nos avanços do capital e na ordem planetária criada por eles, de cuja atualidade as condutas disparatadas de nossa classe dominante são parte legítima” (SCHWARZ, 2000, p. 39). Assim, na nova fórmula, o próprio universalismo aparece problematizado, daí a importância desse passo argumentativo para compreender a grandeza de um autor como Machado de Assis, "capaz de revelar outra engrenagem da parte e do todo [...] resultado da persistência do Antigo Regime num país que o capital ia refazendo" (ARANTES, 1992, p. 20). É esta revelação que o narrador machadiano da segunda fase formulará esteticamente. Ao invés de integrar o particular no universal, ele lança contudo, assinala a diferença. Para ele, os historiadores progressistas de nossa formação econômica e social sinalizavam um movimento de modernização represadora, que não se completara e que transformaria o país se viesse a se completar. Já o livro de Candido constatava no percurso efetivo da literatura nacional um movimento que se completou e que nem por isso transformou o Brasil.

${ }^{4}$ Costa Lima (1992)

problematiza os critérios valorativos de Formação, apontando que apenas a inquestionabilidade da escala de valores tornaria inquestionável a afirmação de que a literatura brasileira é secundária.

Para ele, o livro também é marcado pela ausência da tematização dos próprios valores. Acreditamos, no entanto, com Schwarz (1999), que a operação estabelecida por Candido é, sim, comandada pelo juízo de gosto, influenciado pelo presente, mas mencionado e justificado.

${ }^{5}$ Por isso, como expõe Costa Lima (1992), a ideia de sistema literário nela desenvolvida subordina-se à ideia de coesão nacional, a uma visão nacional coerente. Esse pressuposto de base (e não a ausência da articulação entre 
mão de um e de outro para desautorizá-los reciprocamente. ${ }^{7}$ Como formula Arantes (1992), a dialética identificada por Candido já era capaz de fornecer um balanço da oposição, situando os termos antagônicos no interior de um mesmo movimento. Embora já aí se tratasse de combinação e não dualidade, ${ }^{8}$ a fórmula nem sempre se mantinha capaz de especificar a particularidade histórica do arremate, tarefa que coube a Schwarz ao dar continuidade e adensar o conceito de redução estrutural. ${ }^{9}$ Ao trazer para o primeiro plano a ligação entre processo ideológico e processo social, Schwarz assinalaria o descompasso entre o discurso da ideologia burguesa - que propagava, por exemplo, a possibilidade da ascensão de classe e a autonomia do sujeito livre - e a inércia das relações sociais brasileiras, definidas pela escravidão e pela política de favores, apadrinhamentos e heranças.

Na cultura brasileira, essa disjunção constitutiva se manifestaria, especialmente, na dupla fidelidade aos modelos europeus e aos elementos locais, processo que desencadeou um fenômeno denominado metaforicamente por Schwarz (1999) de “torcicolo cultural”. Nosso país foi, assim, durante toda a sua história, receptor - nem sempre passivo, é verdade - do caldo cultural e artístico (do qual o romance é apenas um dos exemplos) produzido pelos países do velho mundo. Ao mesmo tempo, enquanto colônia no processo de colonização, possuía um desenvolvimento histórico e social diferente dos países europeus, o que conferia um caráter postiço ao mundo das ideias. Essa impossibilidade de importar totalmente os ideais liberais é apresentada, na obra de Schwarz, como característica local do Brasil e como consequência da sua participação na ordem capitalista mundial. A literatura, evidentemente partícipe desse estado de coisas, não poderia deixar de ser plasmada por essas questões e o torcicolo cultural acometeria indireta ou diretamente nossos romancistas. A disjunção estava, assim, fadada a se tornar figuração literária, seja enquanto tema explícito ou matéria inescapável, espécie de “historiografia inconsciente” (ADORNO, 2008, p. 217).

Esse processo conferiu, para além do já assinalado complexo de inferioridade inevitável, inventividade e configurações próprias à literatura aqui produzida, e, muitas vezes, reverteu o seu amálgama em seu quinhão: a originalidade. Poderíamos dizer que nossa submissão tem limites ou, melhor, que nossa submissão é autêntica. As formas artísticas se adaptaram aos temas brasileiros, transformando-se criticamente na medida em que, concomitantemente, se filiavam às formas dadas, mas mantinham-se fieis aos seus contextos. Para Schwarz, a obra machadiana da segunda fase representa o ponto chave da transformação da disjunção em formalização estética. Utilizando-se do acúmulo de outros escritores, Machado, na visão do crítico, ficou em dia com a complexidade objetiva de sua matéria, pois fez com que o elemento social atuasse na construção da própria obra. $\mathrm{O}$ procedimento fica claro em Memórias Póstumas de Brás Cubas, cujo enredo é contado a partir da perspectiva da burguesia brasileira rarefeita. ${ }^{10} \mathrm{O}$ narrador, portanto, deixa de ser uma instância que conta uma história para produção e recepção literárias) explicaria a exclusão da sátira de Gregório de Matos, desvinculada de qualquer propósito nacional, de nosso sistema literário.

${ }^{6}$ No artigo

"Pressupostos, salvo engano, de uma divergência silenciosa: Antonio Candido, Roberto Schwarz e a Modernidade brasileira”, Alfredo Melo aponta as divergências que caracterizam a configuração da dialética nos dois autores. Segundo Melo, uma delas seria a visão "socialista otimista, que deposita imensa fé nas potencialidades do povo" de Antonio Candido e o "pessimismo frankfurtiano" de Roberto Schwarz, que visualiza "um socialismo já sem redenção e a certeza de que o Brasil só integra à modernidade pelas portas do fundo" (MELO, 2014, p.413).

${ }^{7}$ Assim, Brás Cubas atua, ao modo arcaico, na esfera do mando individual, mas, ao mesmo tempo, passa-se, em sua narrativa autodiegética, por uma espécie de "senhorzinho moderno", pois sempre encontra justificativas universalizantes para seus atos caprichosos. Como exemplo, menciona-se a única vez em que ele perde algo, ou melhor, alguém: Virgília. No capítulo LVI, 
ser ele mesmo a própria história. Em suma, o que, até então, teria figurado nos romances antecedentes apenas como assunto, se torna forma. Para desenvolver esta hipótese, Schwarz (2000) recua ao romance Senhora, de José de Alencar, representativo do (des)encontro entre a forma do romance em seus moldes realistas e a matéria local fornecida pela experiência brasileira (da qual Alencar, como bom romântico, foi adepto).

Para Schwarz (2000), portanto, o romance Senhora é marcado pela notação verista, focada na cor local, mas tem o princípio de sua composição (o enredo) movido pelas ideologias do realismo de influência romântica. Em suma, enquanto o núcleo de personagens principais, representados, sobretudo, por Aurélia e Seixas, se mantém preso à dinâmica do dinheiro e, portanto, à ideologia burguesa pressuposta na forma do romance realista europeu, os personagens secundários transitam pela esfera do favor e do oportunismo, expressando, portanto, a lógica local. O crítico, no entanto, não vê uma intersecção entre ambos, ressaltando a incompatibilidade entre a forma europeia do enredo (narrado a partir de discursos sérios e universalizantes) e a tematização da nossa realidade cotidiana, formalizada pela notação mais folgada, próxima à oralidade familiar. Dessa forma, a nossa vida corriqueira teria ficado limitada à tematização dos personagens secundários e sem expressão no nível formal. Como exemplo máximo dessa constatação, Schwarz (2000) menciona o desfecho do romance. O resgate de Seixas que, recuperado, volta a ser bom, é fortemente vinculado pelo crítico às convenções românticas das novelas “sentimentaloides”.

Vemos, portanto, que toda a discussão sobre o caráter disjuntivo da sociedade brasileira - que tentamos retomar nesse preâmbulo um tanto irresponsável, mas necessário para os fins de nossa argumentação - é a base da crítica de Schwarz (2000) sobre Senhora. No entanto, interessado no recuo até Alencar para explicitar o ponto de virada de Machado de Assis, Schwarz (2000) insiste na dualidade do romance expressa pela fórmula "realidade cotidiana expressa nos personagens periféricos" (centrada na inércia de nossas relações sociais) vs. "trama realista de convenção romântica expressa no núcleo principal” (herança do modelo do romance europeu). Reforçase, portanto, o não imbricamento das duas instâncias. Ao não transformar a sociabilidade específica do núcleo periférico em forma, mantendo-o sem relação com o desenvolvimento e com o desenlace, Senhora teria limitado seu princípio formal ao modelo europeu. Assim, pode-se dizer que, para Schwarz, se Alencar lança mão de uma tese e de uma antítese, não chega a realizar a síntese: "Um só romance, mas dois efeitos-de-realidade incompatíveis e superpostos - eis a questão [...] Alencar adere aos dois, a um por sentimento dos costumes, a outro por apreço pela modernidade, que saem puros do livro, tais como entraram”. (SCHWARZ, 2000, p.60, 64, grifo nosso).

Gostaríamos, entretanto, de apresentar uma hipótese de leitura que, sem abrir mão do pressuposto argumentativo da crítica schwarziana, diverge quando relembra do casamento outrora desmanchado, Brás Cubas afirma que então o amor existia, mas que o momento não era oportuno e que, depois, o amor tornou-se oportuno. O discurso é todo travestido de amor e encontra nele a sua razão de ser, mas o capítulo, na realidade, é uma verdadeira defesa do oportunismo.

${ }^{8}$ Cita-se, a título de exemplificação, a sua análise de $O$ Cortiço no texto "A passagem do dois ao três”, no qual Candido critica o binarismo estruturalista e preconiza um terceiro eixo que seria a síntese dialética.

${ }^{9}$ Trata-se da abordagem teórica levada a cabo por Antonio Candido. De matriz marxista e caminho lucaksiano, a redução estrutural prevê a integração do elemento social condicionante, externo à criação artística, à estrutura interna literária. Menciona-se também sua filiação ao new criticism norte-americano e a antropologia social inglesa.

\section{${ }^{10}$ Como a} mercantilização agrária brasileira dependia do processo de escravização e não do trabalho assalariado, impossibilitou-se que se produzisse no Brasil o indivíduo burguês livre, dono de sua força 
da conclusão do crítico. A nossa hipótese é a de que, diferentemente do que aponta Schwarz, há um imbricamento entre a descrição da realidade específica brasileira e a formalização do enredo. Com isso, não se trata de não reconhecer que a trama central tem alguns pontos cegos em relação ao Brasil profundo, mas de considerar que a superposição não é tão total como faz crer o crítico, pois a trama e, sobretudo o desfecho - no qual residiria “a marca do dramalhão romântico, da futura radionovela” (SCHWARZ, 1999, p. 43) - aparecem permeados por algumas relações do Brasil patriarcal, com destaque de uma delas. Para demonstrar nossa hipótese, começaremos, pois, pelo fim da obra e analisaremos a natureza mesma do resgate de Seixas. Na quarta e última parte do livro, já sabemos que Seixas recusava o acesso aos luxos da casa que outrora tanto desejara. Predispôs-se, assim, a comprar de volta a sua liberdade. Para isso, utilizou os vinte mil cruzeiros em dinheiro que havia sido adiantado por Lemos no momento do acordo e o cheque de oitenta mil cruzeiros entregue por Aurélia no dia do casamento (que foi devolvido intacto). Fazendo, porém, jus à justiça pressuposta na troca mercantil, Seixas devia ainda à Aurélia o juro da quantia em dinheiro. Portanto, uma parte do dinheiro que lhe permite completar o necessário para o resgate - como veremos, nem tão nobre assim - vem de duas situações, a nosso ver, brasileiríssimas: um privilégio, o direito de explorar a terra aliado à corrupção, e o conluio entre o público e o privado. Para notá-lo, devemos nos deter em um acontecimento significativo da obra. Um dia, ao sair da repartição, Seixas encontrou Barbosa, negociante e antigo conhecido, que lhe deu uma boa e oportuna notícia: o privilégio da exploração de algumas minas de cobre que Seixas, Fróis e Barbosa haviam impulsionado, finalmente havia rendido dinheiro:

Começara a desenvolver-se a febre das empresas; um espertalhão teve a idéia da exploração de umas minas de cobre em São Paulo; e para obter a concessão lembrou-se de associar à especulação um negociante que fornecesse fundos, e um empregado que abrisse os canais administrativos. Seixas achava-se em relações com o Fróis, e veio a ser o empregado escolhido. A seu pedido o requerimento subiu ao ministro, como um balão, cheio de gás de pomposas informações. O despacho não se demorou. $\mathrm{O}$ oficial de gabinete o alcançara fumando um charuto com seu ministro, e dando-lhe os mais amplos esclarecimentos, não sobre a projetada empresa, mas sobre uma bela mulher, por quem a excelência se apaixonara. Concedido o privilégio, tratou o Fróis de negociá-lo, muito esperançoso de obter pelo menos uns trezentos mil cruzeiros [...] (ALENCAR, 19--, p. 122, grifo nosso).

O privilégio, é certo, não rendeu o dinheiro esperado, mas conseguiu finalmente ser vendido em Londres por cinquenta mil cruzeiros, o que conferiu a Seixas, deduzidas as despesas, a terça parte no valor de quinze mil cruzeiros, por ter... azeitado a máquina estatal! Embora a ação corrupta seja de trabalho e que, portanto, deveria esforçar-se para vendê-la, enredo constante na literatura europeia. Portanto, como esclarece Schwarz (1999), os grandes temas nos quais a forma do romance se ancora ficavam aqui necessariamente modificados.

Assim, se o escritor provinciano Lucien Du Rubempré, em As ilusões perdidas (obra significativa do realismo francês), de Honoré de Balzac, parte do interior da França para Paris e descobre na nascente indústria da cultura a oportunidade de ascender socialmente, nosso Brás Cubas em Memórias Póstumas (expressão do realismo brasileiro), nascido em uma típica família da elite carioca do século XIX, vaga tediosamente pela vida, é induzido à política pelo pai, mas nutre apenas a ânsia de ficar conhecido por todos. Por isso, a opção estética por retratar temas brasileiros rapidamente revelou que isso implicaria também em mudanças formais. Machado de Assis imprimiu ao romance realista configurações próprias que, em muito, se distanciam da forma do romance realista tal como concebida na Europa. 
atribuída ao comportamento de Seixas antes do casamento, o personagem não titubeia (ou, como lhe cai melhor, titubeia apenas por um momento) em aceitar o valor de origem escusa para conseguir algo tão nobre como... sua própria liberdade! Diante de tão importante necessidade pessoal - aliada à suspeita de um caso entre Aurélia e Abreu - faz-se “sacrifícios”: “Quaisquer, porém, que fossem seus escrúpulos, ele carecia desse dinheiro, e julgava-se com direito de empregá-lo em serviço de tamanho alcance, como era aquele a que o destinava [...]” (ALENCAR, 19--, p. 123). A sua determinação, assinalada pelo narrador logo em seguida, de restituir a quantia por outro meio indireto com o fim de aliviar sua própria consciência, contudo, não chega a fazer parte da trama. Ora, estivesse Alencar mais atento às convenções do romantismo do que ao Brasil profundo e Seixas poderia ter conseguido esse dinheiro num lance de sorte, em uma aposta, um jogo de cartas ou uma corrida de cavalos. Tivesse Seixas, de acordo com a convenção, se transformado de fato em um homem tão digno e preferiria trabalhar por mais anos a se vender por quinze mil cruzeiros.

Não só esta situação narrativa, entretanto, vem corroborar a nossa hipótese. Sabemos, também, que o cheque, o dinheiro de Aurélia e a quantia proveniente da exploração das minas não seriam suficientes para o resgate. Para completá-lo, Seixas utiliza também toda a remuneração de seu trabalho na repartição onde, para espanto de todos, passou a ser assíduo. No entanto, podemos fazer a seguinte pergunta: como é possível que alguém guarde todo o seu salário? A resposta não poderia remeter mais ao Brasil do século XIX: vivendo justamente de favor. Em troca das aparências de um casamento perfeito, Seixas tem a possibilidade de dormir, se alimentar e, inclusive, fumar charutos... na casa de Aurélia, sem gastar nada com isso. Não podemos - ou ao menos não devemos - considerar grande esforço e mérito comer os caros cachos de uvas apenas diante da insistência de Aurélia e ficar sem comprar roupas por onze meses, de modo que seu suposto martírio não soa senão risível. Ainda mais se considerarmos que, para se salvar, Seixas deixa de gastar o pouco dinheiro que gastava com a família. A situação do desenlace, portanto, se examinada mais de perto, revela pouquíssimo sacrifício para a dignidade romântica que lhe foi atribuída. Lido mais atentamente, o desfecho parece mesmo merecer que lhe seja questionada a sua eficácia em glorificar os valores burgueses.

Notamos, assim, que por trás da organização deste núcleo principal não está apenas a lógica capitalista da troca mercantil, mas também a extensão da lógica do contrato e do favor. Toda a dinâmica da sociedade brasileira atua ativamente por trás do resgate que foi visto pela crítica como uma trama exclusivamente europeia. O final simplesmente depende da interpenetração das duas realidades que, portanto, diferente do que afirmou Schwarz (2000), não saem tão puras como entraram. Se aquilo que permite o resgate é justamente aquilo que impediria o resgate pleno, podemos dizer que a disjunção brasileira repousa no cerne mesmo do desfecho. Como procuramos demonstrar, Seixas 
não se resgatou de modo totalmente digno de acordo com os paradigmas da sociedade burguesa, o que aponta para uma potencialidade do romance de Alencar que, aparentemente, passou despercebida. Talvez nele já estivesse inscrita a falácia ideológica de certo universalismo, já que o resgate indigno pode apontar, ainda que timidamente, para a impraticabilidade da própria ideologia. Dessa forma, a representação da impossibilidade de readquirir a honra de modo completamente íntegro não deixa de ser um atestado da falácia do próprio paradigma burguês.

Podemos dizer, portanto, que o casamento, cerne do conflito central do romance, não se reduz apenas ao seu aspecto essencial de compra e venda como era o costume da época inclusive na Europa. O resgate de Seixas nesses moldes depende de seu vínculo com a sociedade brasileira, o que confere a ela estatuto formal. Embora seja possível admitir que existem uma trama brasileira e uma europeia, não parece ser possível concordar com a afirmação de que não há interpenetração entre elas. Nesse sentido, nossa argumentação diverge da leitura de Roberto Schwarz (2000) e se aproxima da recepção crítica do romance por Antonio Candido (2006). Embora Candido (2006) não tenha desenvolvido seu argumento, atinou não só para o fato de que o próprio assunto da obra tratava da representação e dos costumes do Brasil da época, mas também para o fato de que esse traço social contribuía para formar a estrutura do livro. Ao compor o cerne do conflito central, o caráter disjuntivo das relações e do comportamento brasileiros desempenha certo papel também na constituição da estrutura da obra, tornando-se, portanto, elemento interno.

Para nossa hipótese contribui também a constatação de que as relações de favor permeiam o núcleo dos personagens centrais não apenas no desfecho, de modo que o favor aparece na obra como uma mediação social de relevo indiscutível. Antes do desfecho, Seixas, e mesmo Aurélia, já dependem dele. Aurélia, quando perde os pais, vive de favor com Dona Firmina, relação que, posteriormente, tão logo a moça se torna rica, se inverte. Logo no início do romance, quando Firmina conta-lhe suas impressões do baile de véspera, evidencia-se a sociabilização típica de um país na periferia: “D. Firmina continuou por aí além a descrever suas impressões do baile de véspera, sem tirar os olhos do semblante de Aurélia, onde espiava o efeito de suas palavras, pronta a desdizer-se de qualquer observação, ao menor indício de contrariedade” (ALENCAR, 19--, p. 4). Notamos, pela passagem, a vulnerabilidade de Dona Firmina que, privando-se de qualquer espontaneidade, mostra-se movida por um jogo de interesses muito claro. A sua opinião depende exclusivamente da reação de Aurélia, daí a necessidade de emiti-las sempre olhando para a moça.

O caso de Seixas, no entanto, é ainda mais explícito que o de Aurélia. Filho de um empregado público e órfão de pai aos dezoitos anos, Seixas foi obrigado a abandonar seus estudos na Faculdade de São Paulo. O narrador 
deixa claro que, se a natureza tivesse lhe dado energia e força de vontade, ele conseguiria concluir o curso, "tanto mais quanto um colega e amigo, o Torquato Ribeiro, lhe oferecia hospitalidade até que pudesse liquidar o espólio” (ALENCAR, 19--, p. 17). Seixas, porém, era um espírito que, segundo o narrador, preferia a trilha batida, o que o fez ceder "à instância dos amigos de seu pai que obtiveram encartá-lo em uma secretaria como praticante” (ALENCAR, 19--, p. 17, grifo nosso). Ainda em outro momento, ao relatar as preocupações de Seixas, o narrador enfatiza que uma delas é a conversa que teria no baile com uma mulher, contando "granjear os favores da senhora, com a mira de alcançar por seu empenho a proteção do ministro para um acesso” (ALENCAR, 19--, p. 18, grifo nosso). Na página seguinte, vemos que, provavelmente, o empenho em conseguir uma influência feminina surtira o efeito esperado, pois somos informados de que a renda de Seixas subiu para sete mil cruzeiros "em virtude de uma comissão que lhe deu o ministro, por haver simpatizado com ele” (ALENCAR, 19--, p.19--, grifo nosso). Todas essas situações narrativas apontam para a condição de Seixas de homem livre que precisa sobreviver no Império, assim como Lemos. Para levar adiante a empreitada, lança mão do favor e do conluio entre o público e o privado. O favor e o conluio (e, no caso de Aurélia, a herança) aparecem, assim, como as formas principais de ascensão social para os homens livres que, portanto, não partilham apenas as concepções do Realismo francês em matéria de dinheiro e amores. Estas situações explicam o motivo pelo qual podemos afirmar que Alencar ficcionaliza a matéria social brasileira no próprio enredo dos personagens centrais e não apenas no núcleo dos personagens secundários, como constatou a crítica literária canônica. A conclusão que emana da reunião dessas passagens é a de que já há em Alencar o hibridismo brasileiro de pertencimento inacabado ao capitalismo, o que confere ao núcleo principal uma forma dupla de sociabilidade que permite atribuir a este romance uma lógica de base que foi observada pela crítica apenas na ficção brasileira posterior.

Além do mais, a crença no resgate pleno de Seixas, tal como o representaria a convenção de veio romântico, deveria estar coerentemente respaldada na descrição dos atos e da interioridade do personagem para além do desfecho. A premissa do romantismo, contudo, - o homem é bom, mas a sociedade o corrompe - não parece corresponder adequadamente a sua trajetória. Observando o comportamento do personagem ao longo de toda a trama, podemos e devemos nos perguntar o que nas cenas nos permite pensar que ele é, de fato, resgatável. Pensemos, primeiro, na sua relação com seus familiares. Além de gastar consigo mesmo mais do triplo da subsistência de toda a família, Seixas precisa ouvir as amigas sugerindo a sua mãe e irmã que pedissem a ele para levá-las ao teatro para, só então, tomar consciência de que, “enquanto lhe minguavam as horas para os prazeres de que se fartava, aquelas três senhoras ali desfiavam as compridas noites sem outro entretenimento além da tarefa jornaleira ou daqueles ecos do mundo” 
(ALENCAR, 19--, p. 19) A súbita descoberta, contudo, não o impediu de fincar a cabeça no travesseiro e dormir "o sono do justo" (ALENCAR, 19-, p. 19). Ainda que Seixas, logo depois, tenha levado as irmãs e a mãe na primeira noite da Representação Lírica, ele não o faz sem certo arrependimento esnobe. Acaba, pois, por concluir - à Brás Cubas - que teria sido melhor às "roceiras" ficarem em casa, com seus vestuários tão alheios às modas e usos da sociedade. Certamente, não lhe ocorreu que isso também acontecia porque a mãe costurava as próprias roupas, enquanto ele ia ao melhor alfaiate.

Pensemos também na sua relação com o amor. O narrador, desde o início, não deixa dúvidas sobre o caráter de Seixas: “O casamento, desde que não lhe trouxesse posição brilhante e riqueza, era para ele nada menos que um desastre” (ALENCAR, 19--, p. 57, grifo nosso). Claramente interessado em prover unicamente o seu próprio luxo - e já acostumado a isso entre sua família - o caráter de Seixas só lhe permitiria relacionar-se unicamente por dinheiro. A metáfora empregada pelo narrador dá dimensão suficiente da importância do reconhecimento social em detrimento de qualquer felicidade e amor genuínos e é suficiente para dar a medida de seu egoísmo e de sua sordidez. Afinal, qualquer casamento que não corresponda às expectativas certamente recai em desgosto ou infelicidade, mas, para Seixas, ganha a dimensão mínima de um desastre. Mais adiante, ao afirmar que Seixas era um homem honesto, o narrador assinala que sua honestidade, porém, diante do calor das salas e do atrito da secretaria, ganhara caráter maleável. Era uma honestidade, portanto, que se tornaria facilmente moldada "às fantasias da vaidade e aos reclamos da ambição” (ALENCAR, 19--, p. 27). É evidente a complacência do narrador em relação a Seixas. Isso porque a passagem atribui justificativas deterministas para a honestidade questionável do personagem para, logo em seguida, construir-se por meio de uma afirmação positiva. Primeiro, conta aquilo que Seixas seria incapaz de fazer - "Era incapaz de apropriar-se do alheio, ou de praticar um abuso de confiança” (ALENCAR, 19--, p. 27). No entanto, a conjunção adversativa “mas”, que vem a seguir, não deixa dúvidas: apesar dessas qualidades, professava a moral fácil e cômoda e, por isso, o interesse próprio teria, para ele, plena liberdade, desde que evitasse o escândalo. Ora, não precisamos de muito para identificar aqui a lógica de funcionamento típica da sociedade brasileira. Essa lógica motiva as suas ações na trama e, ao longo da obra, se torna ainda mais evidente. Lembremo-nos de que Seixas elege Aurélia como pretendente, mas arrepende-se de assumir compromisso com uma moça pobre. Por isso, prefere se comprometer com Adelaide, moça rica e já da alta sociedade. Tão logo Aurélia enriquece com a herança, surge-lhe o alto dote misterioso e tentador que faz com que Seixas tenha de desvencilhar-se da promessa de casamento feita ao pai de Adelaide: 
A promessa feita ao pai de Adelaide era explícita e formal. Em caso algum Seixas se animaria a negá-la e faltar desgarradamente à sua palavra; mas como não se obrigara a realizar o casamento em prazo fixo, esperava do tempo, que é grande resolvente, uma emergência feliz o libertasse (ALENCAR, 19--, p. 57).

A linguagem floreada não deve enganar. É fundamental notar que o narrador não diz que "em caso algum, Seixas negaria a promessa e faltaria à sua palavra”, mas sim que ele "não se animaria a negá-la e faltar desgarradamente” à ela. Essa estratégia de construção não ocorre por acaso e o uso do advérbio de modo tem implicações. O que está posto nas entrelinhas desse discurso não é que Seixas não faltaria à promessa, mas que não faltaria de modo escancarado, sem qualquer pudor. Por trás do caráter vacilante da linguagem está a complacência (quem sabe, até de classe) daquele que narra, o que pode indicar já aí uma desfaçatez de classe do próprio personagem, embora filtrada a partir da perspectiva do narrador, daí a diferença em relação ao modo como atua essa desfaçatez em Brás Cubas, ele mesmo narrador e personagem. Seixas apega-se, portanto, à própria brecha de seu acordo nem tão formal. Afinal, não havia combinado nem um prazo fixo ou, mesmo que tivesse combinado, "não se obrigara a realizar o casamento em prazo fixo” (ALENCAR, 19--, p. 58). Ainda que a linguagem, rebuscada e afetada, pareça um clichê, ela concorre para que o leitor seja introduzido ao comportamento frívolo do personagem. O contraste irônico entre forma e conteúdo indica, assim, as suas motivações escusas e relativiza o tom sério-realista do discurso burguês que Schwarz (2000) atribui à narração do núcleo principal. Ou seja, os procedimentos são os dessa convenção, mas o efeito é outro, porque a matéria também o é. Isso nos leva a desconfiar de que a linguagem de Alencar seja apenas algo "empolado e acrítico desprovido de malícia” (SCHWARZ, 2000, p.47), um simples acatamento à vida das ideias europeias.

Gostaríamos de destacar, ainda, mais uma passagem que tem rendimento e que, junto com as demais já citadas, podem contribuir para demonstrar que o romance de Alencar é indissociável do tema da formação brasileira. O trecho seguinte não só o indica, mas também o desdobra em direção a outra característica latente que, em nossa experiência social do século XIX, o indivíduo acabava por adquirir:

Quando Seixas convenceu-se que não podia casar com Aurélia, revoltou-se contra si próprio. Não se perdoava a imprudência de apaixonar-se por uma moça pobre a quase órfã, imprudência a que pusera remate o pedido de casamento. O rompimento deste enlace irrefletido era para ele uma coisa irremediável, fatal; mas o seu procedimento o indignava. Havia nessa contradição da consciência de Seixas com a sua vontade uma anomalia psicológica, da qual não são raros os exemplos na sociedade atual. $O$ falseamento de certos princípios da moral, dissimulado pela educação e 
conveniências sociais, vai criando esses aleijões de homens de bem. Quem não conhece o livro em que Otávio Feuillet glorificou sob o título de honra as últimas hesitações de uma alma profundamente corrompida? Seixas estava muito longe de ser um Camors; mas já nele começava o embotamento do senso moral [...] (ALENCAR, 19--, p. 53-54, grifo nosso).

Ressalta-se, na passagem, o caráter vacilante de Seixas, resultado da conjunção do discurso universalizante do capitalismo e do desdobramento prático das relações típicas brasileiras. Sabemos que Schwarz (2000) encontrou na oscilação de Brás Cubas entre essas duas esferas a condição daquele que é, ao mesmo tempo, indivíduo isolado e livre, ao modo moderno, e igualmente um senhor que exerce a dominação direta sobre os outros, ao modo arcaico. Essa conjunção disparatada daria ensejo àquilo que Schwarz denomina como a volubilidade do narrador machadiano. Para nós, essa volubilidade já está presente em Seixas, registrada, é certo, em terceira pessoa - daí a emanação do tom moralizante e não cínico, mas jamais inconsciente. Ao considerar uma imprudência ter se apaixonado por uma moça pobre, Seixas não deixa de se autocensurar. No cerne de seu conflito moral repousa o embate entre o desejo de se casar exclusivamente por dinheiro e a indignidade de faltar com a palavra à Aurélia. A “anomalia psicológica”, contudo, não é registrada apenas aí. Basta observarmos que a maior parte das descrições de Seixas, de seu caráter e espírito, é construída por meio de uma afirmação seguida de relativização ou negação. ${ }^{11}$ Isso revela que as crispações universalizantes do discurso burguês não poderiam atuar sobre ele senão como meras crispações, o que por si só acaba por relativizar a “seriedade” e o tom moralizante que Schwarz atribui à descrição dos personagens do núcleo principal. A estrutura se repete também no trecho acima: "Não se perdoava a imprudência de apaixonar-se por uma moça pobre a quase órfã [...] mas o seu procedimento o indignava” (ALENCAR, 19--, p. 57). Este tipo de estrutura frasal empregada pelo narrador quase sempre que se refere a Seixas indica que o discurso universalizante pode atuar sobre o personagem apenas como pensamento, vislumbre distante, ideologia, para logo ser recusado em nome de um motivo concreto, quase sempre egoísta, mas sempre pautado na sociabilidade à brasileira.

A construção frasal acaba funcionando, assim, como expressão retórica de uma individualidade "cindida entre dois regimes contraditórios de concepção de si e de sua relação com o outro que, logicamente, deveriam se excluir, mas que se encontram combinados e atestados pela realidade da experiência” (PASTA JR., 2011, p. 101-102). As palavras destacadas - “contradição da consciência”, "anomalia psicológica” - e a recorrência desse tipo de estrutura frasal nas descrições de Seixas revelam que Alencar foi capaz de registrar esse movimento da subjetividade, isto é, assimilá-lo artisticamente. Pasta Jr. (2011), buscando desenvolver as ideias de Schwarz, rastreia ao longo do desenvolvimento do romance brasileiro esse tipo de
${ }^{11}$ Ao modelo daquela já citada e comentada: "Se a natureza lhe tivesse dado energia e força de vontade [...] mas Seixas era desses espíritos que preferem a trilha batida [...]" (ALENCAR, 19--, p.17). 
comportamento fixado no “entre dois”, o que denominará como “formação supressiva”: a saída encontrada por uma subjetividade que deve conceber sua diferença em relação ao outro e, ao mesmo tempo, não deve de modo algum concebê-la. Ao analisar essa espécie de movimento pendular da consciência, responsável por ensejar uma sequência-tipo na história de nossa literatura, o crítico recorre justamente a Senhora:

Quando se observa esse conjunto, sob diversos aspectos bastante heterogêneo, vê-se entretanto que ele manifesta um traço comum, talvez o mais saliente: os heróis desses romances são, todos eles, muito cambiantes e alguns deles o são de modo muito espetacular, até mesmo algo desconcertante [...]. Esse é bem o caso, creio eu, de Aurélia, a heroína de Senhora. Nada a impede de cantar repentinamente as árias da Norma ao despertar, de comportar-se como moça piedosa, sonhadora e afetuosa pela manhã, de ser ferozmente voraz no almoço, comendo rosbife por quatro, de conduzir-se como mulher do mundo após o meio-dia e de ter propósitos cínicos, até mesmo libertinos e escandalosos, à noite, nas festas e nos bailes (PASTA JR., 2011, p. 97).

Algo dessa metamorfose incessante - que, no modernismo, encarnará em Macunaíma - já existe em Aurélia, assim como a volubilidade do espírito - tributada pela crítica apenas aos personagens dos romances do segundo Machado - já caracteriza Seixas. Podemos dizer que Senhora, portanto, tematiza e formaliza essas questões, embora de maneira mais tradicional, mas já por meio de um narrador que fala com racionalidade cartesiana cristalina sobre a dubiedade do personagem, ainda que não faça com que o próprio personagem em sua dubiedade nos apareça. Este tipo de construção retórica para caracterizar o personagem leva ao desmascaramento e nela já reside a matéria bruta brasileira. A psicologia de Seixas, como vimos, não é a psicologia de personagens que estava à mão enquanto modelo, porque o sujeito ficcionalizado já aparece formado a partir da perspectiva do capitalismo à brasileira: a formação é possibilitada pela supressão da formação. O narrador de Senhora já atua sob essa perspicaz percepção, um pouco desdenhada pela crítica. Em suma, o ponto de nossa argumentação é o de que há um desprestígio imerecido do romance Senhora, o que se deve, em parte, à ligeireza do texto e à profundidade relativa dos personagens, ambos aliados a uma postura crítica que mede - com as melhores intenções e com bons resultados - as obras anteriores com a régua do segundo Machado de Assis. Desse modo, não apenas a potencialidade de Senhora, mas também a potencialidade dos primeiros romances machadianos passou despercebida em prol de uma argumentação que, para evidenciar a grandeza das obras maduras, reforçou as lacunas das obras anteriores. Perdeu-se, assim, uma leitura dessas obras nos seus próprios termos, tarefa que procuramos realizar neste artigo e costume pouco frequente num país em que se acusa frequentemente o caráter secundário de alguns livros. Com isso, não queremos 
dizer que não haja uma diferença e uma guinada formal entre as obras, já que as conquistas formais nunca acontecem abruptamente. Reafirmamos, portanto, o reconhecimento da importância de toda a obra crítica de Schwarz que, inclusive, utilizamos livremente como pressuposto e ponto de partida de nossas análises. Isso, no entanto, não deve impedir a constatação de que Senhora tem mais sentido do que lhe atribui o crítico, que vê no romance apenas a superposição sem consequência formal de duas realidades.

\section{Agradecimentos}

Agradeço ao professor Luís Bueno (UFPR), responsável pela minha dedicação aos temas aqui desenvolvidos.

\section{Referências}

ADORNO, Theodor W. Teoria estética. Tradução de Artur Morão. Lisboa: Edições 70, 2008.

ALENCAR, José de. Senhora: perfil de mulher. 4. ed. [s.l.]: Melhoramentos, [19--].Texto proveniente de: A Biblioteca Virtual do Estudante Brasileiro http://www.bibvirt.futuro.usp.br. Acesso em: 06 out. 2017.

ANDRADE, Mário de. A lição do amigo: cartas de Mário de Andrade a Carlos Drummond de Andrade, anotadas pelo destinatário. São Paulo: Companhia das Letras, 2015.

ARANTES, Paulo Eduardo. Sentimento de dialética na experiência intelectual brasileira: dialética e dualidade segundo Antonio Candido e Roberto Schwarz. Rio de Janeiro: Paz e Terra, 1992.

ASSIS, Machado de. Memórias póstumas de Brás Cubas. In: Obra Completa. Vol. I. Rio de Janeiro: Nova Aguilar, 1994.

PASTA JR., José Antonio. Formação supressiva: constantes estruturais do romance brasileiro. 2011. Tese (Livre-docência em Literatura Brasileira), - Faculdade de Filosofia, Letras e Ciências Humanas - Universidade de São Paulo, 2011.

SCHWARZ, Roberto. Ao vencedor as batatas: Forma literária e processo social nos inícios do romance brasileiro. São Paulo: Duas Cidades / Ed. 34, 2000.

. Os sete fôlegos de um livro. In: Sequências brasileiras: ensaios. São Paulo: Companhia das Letras, 1999. p. 46-58.

Um mestre na periferia do capitalismo: Machado de Assis. São Paulo: Duas cidades, 1990. 
CANDIDO, Antonio. Formação da literatura brasileira: momentos decisivos. Belo Horizonte: Editora Itatiaia Ltda, 2000.

Crítica e sociologia (tentativa de esclarecimento). In: Literatura e Sociedade. Rio de Janeiro: Ouro sobre Azul, 2006. p.12-17.

COSTA LIMA, Luiz. Concepção de história literária na "Formação". In: DUNCÃO, Maria Angela; SCARABÔTOLO, Eloísa Faria. Dentro do texto, dentro da vida: ensaios sobre Antonio Candido. São Paulo: Companhia das Letras e Instituto Moreira Salles, 1992. p. 153-169.

MELO, Alfredo Barbosa de. Pressupostos, salvo engano de uma divergência silenciosa: Antonio Candido, Roberto Schwarz e a modernidade brasileira. Alea, Rio de Janeiro, v. 16, n. 2, p. 403-420, jul./dez. 2014.

Recebido em agosto/2018.

Aceito em dezembro/2018. 